\title{
Pengaruh Persepsi dan Preferensi Konsumen terhadap Keputusan Pembelian Hunian Green Product
}

\author{
Widya Wardhani \\ Program Pascasarjana Manajemen dan Bisnis \\ Institut Pertanian Bogor \\ Kampus MB IPB Padjajaran Bogor \\ e-mail: wardhani.widya@gmail.com \\ Ujang Sumarwan \\ Departemen Ilmu Keluarga dan Konsumen, Fakultas Ekologi Manusia \\ Institut Pertanian Bogor \\ Kampus Darmaga Bogor 16680 \\ Lilik Noor Yuliati \\ Departemen Ilmu Keluarga dan Konsumen, Fakultas Ekologi Manusia \\ Institut Pertanian Bogor \\ Kampus Darmaga Bogor 16680
}

\begin{abstract}
The purposes of this study are: 1) to identify factors that influence consumer perceptions on green product purchase decisions; 2) to identify factors affecting consumer preferences of green product purchase decision; 3) to analyze the influence of consumer perceptions and preferences of green product purchase decision. Data obtained from 151 respondents were divided into two groups, and the respondents are resident and non-resident of Puri Botanical Residence. In this study, a model with 30 indicators (27 exogenous indicators, 3 endogenous indicators) was developed. Data were then analyzed using Partial Least Square Analysis with SmartPLS program. It was found that products, facilities, developer images, payment methods and environmental have a significant influence on consumer's purchase decision, but other variables such as prices, promotion, and social factor do not have significant influence on consumer's purchase decision.

Keywords: consumer perceptions, consumer preferences, green product, partial least square, purchase decision

\section{ABSTRAK}

Tujuan dari penelitian ini adalah: 1) Mengidentifikasi faktor-faktor yang mempengaruhi persepsi konsumen terhadap keputusan pembelian green product hunian; 2) Mengidentifikasi faktor-faktor yang mempengaruhi preferensi konsumen keputusan pembelian green product hunian; 3) Menganalisis pengaruh persepsi konsumen dan preferensi keputusan pembelian green product hunian. Data yang diperoleh dari 151 responden dibagi menjadi dua kelompok yaitu kelompok penghuni dan kelompok non penghuni. Dalam penelitian ini, dikembangkan model dengan 30 indikator (27 indikator eksogen, 3 indikator endogen). Data dianalisis dengan Analisis Partial Least Square menggunakan program SmartPLS. Kesimpulan dari penelitian ini adalah variabel produk, fasilitas, citra pengembang, metode pembayaran dan lingkungan memiliki pengaruh yang signifikan terhadap keputusan pembelian green product hunian, sementara variabel harga, promosi, dan faktor sosial tidak berpengaruh secara signifikan.

Kata kunci : persepsi konsumen, preferensi konsumen, produk ramah lingkungan, partial least square, keputusan pembelian
\end{abstract}


46|Wardhani, Sumarwan, Yuliati - Pengaruh Persepsi dan Preferensi Konsumen

\section{Pendahuluan}

Permasalahan urbanisasi akibat pesatnya perkembangan kegiatan perekonomian di DKI Jakarta menciptakan kebutuhan akan tempat tinggal yang semakin meningkat. Salah satu hal terlihatnya peningkatan kebutuhan akan hunian di DKI Jakarta ditandai dengan maraknya pasar properti di Indonesia. Memasuki tahun 2013, perkembangan pasar properti Indonesia diprediksi terus meningkat. Melihat perkembangan tersebut, maka usaha dalam bidang properti dapat dikatakan terus meningkat, semakin terbuka lebar dan berkembang pesat. Besarnya peranan bangunan seperti rumah dan gedung perkantoran terhadap kerusakan lingkungan memiliki potensi untuk tidak menyelamatkan lingkungan. Hal ini dikarenakan pelaku yang terkait dengan pembangunan sangat banyak sekali, mulai dari pemilik bangunan, perencana, pembangun, pengoperasi hingga penghuni. Oleh karenanya, untuk mengantisipasi kerusakan bumi dapat dilakukan dengan mengimplementasi-kan suatu konsep bangunan ramah lingkungan atau biasa disebut dengan konsep "green building", dimana konsep tersebut menuntut suatu bangunan untuk sangat memperhatikan aspek lingkungan, mulai dari tahap perencanaan, proses pembangunan, pemilihan bahan bangunan, instalasi hingga masa operasionalnya (Firsani dan Utomo 2012).

PT. Copylas Indonesia adalah salah satu perusahaan di Divisi Residensial dari PT. Jakarta Setiabudi International Tbk, sebuah Perusahaan Pengembang dan Investasi Properti terkemuka di Indonesia. Dengan memperhatikan UU No. 26 Tahun 2007 tentang penyediaan Ruang Terbuka Hijau, membangun hunian bernuansa hijau yang memiliki 6.5 hektar taman botanik yang eksotik. Hunian ini dinamakan Puri Botanical Residence, dimana terletak di area Joglo-Kembangan, Jakarta Barat. Puri Botanical Residence mengusung konsep 'urban \& green' dengan dihadirkannya hunian yang dilengkapi dengan taman botanik pertama yang ditanami begitu banyak tanamantanaman langka, dikembangkan bekerja-sama dengan Pusat Konservasi Kebun Raya Bogor. Konsep ini menghadirkan harmoni atau keselarasan antara gaya hidup urban modern dengan gaya hidup ramah lingkungan. Sebagai hasilnya, di tahun 2010 Puri Botanical Residence kembali mendapat penghargan dari Majalah Property \& Bank sebagai "Perumahan Urban yang Konsisten Mengusung Konsep Kota Hijau", serta "Green Property Award 2010" dari majalah Housing Estate. Dengan konsep yang ditawarkan tersebut, diharapkan menarik minat konsumen untuk memilih green product hunian. Hal ini dikarenakan pula kesadaran masyarakat yang meningkat tentang pentingnya menjaga kelestarian lingkungan hidup membuat banyak produsen dari berbagai macam produk mulai beralih menggunakan atau memberi fasilitas menggunakan bahan-bahan yang tidak merusak lingkungan.

Pengambilan keputusan konsumen adalah aspek penting bagi pemasar karena untuk menentukan apakah konsumen akan melakukan pembelian atau tidak melakukan pembelian atas keputusan yang konsumen tetapkan. Keputusan konsumen terkait erat dengan informasi yang dimiliki konsumen dan berbagai faktor dan berbagai faktor yang dipengaruhi oleh pengetahuan konsumen tentang produk yang akan dibelinya (Sumarwan 2011). Dalam proses pengambilan keputusan konsumen, pengaruh situasi konsumen akan memberikan hasil akhir yang berbeda untuk masingmasing konsumen. Tahapan pencarian informasi juga dipengaruhi oleh tingkat kebutuhan konsumen terhadap produk yang dicarinya. Keputusan konsumen dipengaruhi oleh faktor-faktor lingkungan eksternal seperti fakor kebudayaan, sosial, pribadi dan psikologis (Kotler dan Amstrong 2008). 
Persepsi didefenisikan oleh Kotler (2002) sebagai proses seorang individu dalam memilih, mengorganisasikan dan menafsirkan masukan dan informasi untuk menciptakan sebuah gambar yang bermakna tentang dunia. Persepsi merupakan aktivitas penting yang menghubungkan konsumen individual dengan kelompok, situasi dan pengaruh pemasar (Hawkins et al. 1997). Craven (1997) mendefinisikan persepsi sebagai proses dimana individu memilih, mengorganisasi dan mengintepretasikan stimuli ke dalam gambaran yang mempunyai arti dan masuk akal sehingga dapat dimengerti. Persepsi meliputi semua proses yang dilakukan seseorang dalam memahami informasi mengenai lingkungannya, sehingga proses pemahaman ini akan mempengaruhi cara seseorang mengorganisasikan persepsinya. Sejumlah penelitian telah menentukan hubungan antara harga dan persepsi konsumen terhadap kualitas produk (Rao dan Monroe 1988) sedangkan kualitas yang dipersepsikan didefinisikan sebagai keputusan konsumen tentang superioritas dari suatu produk (Zeithaml 1988). Dalam hal pemilihan green product, bahwa segala sesuatu yang dipersepsikan konsumen tentang lingkungan akan memberikan wawasan terbesar pada kesadaran konsumen akan lingkungan (Straughan dan Robert 1999).

Sulistiyowati (2008) melakukan penelitian mengenai pengaruh persepsi atas produk dan pelayanan terhadap kepuasan pelanggan dan perilaku word of mouth (WOM). Dalam penelitian ini menyebutkan bahwa bagi perusahaan hal persepsi pelanggan atas performa jasa dan produk yang dikonsumsi memegang peranan sangat penting atas keberhasilan perusahaan. Karena begitu pentingnya peran pelanggan terlebih didukung iklim usaha yang saat ini sangat kompetitif, maka posisi pelanggan semakin terasa sebagai raja. Faktor-faktor persepsi konsumen terhadap keputusan pembelian hunian antara lain lokasi, produk, harga dan cara bayar, promosi dan fasilitas (Rustandi 2012). Sedangkan menurut Dahmiri (2010) indikator-indikator yang mengukur tingkat persepsi konsumen antara lain harga rumah, kualitas, model dan tipe rumah, fasilitas, lokasi perumahan, dan sistem pembelian. Menurut Nazir (2008) persepsi kualitas atribut perumahan terhadap willingness to accept secara umum adalah persepsi aksesibilitas, kondisi lingkungan, dan karakteristik fisik rumah.

Assael (1992) mendefinisikan preferensi adalah kesukaan, pilihan atau sesuatu yang lebih disukai konsumen. Penelitian mengenai preferensi konsumen terhadap suatu produk telah dilakukan sebelumnya, pada beberapa penelitian dan perusahaan yang berbeda. Hal ini mengindikasikan bahwa preferensi konsumen merupakan hal yang penting dalam pemasaran karena berhubungan erat dengan keberhasilan perusahaan untuk mencapai tujuannya, yaitu keputusan pembelian yang dilakukan oleh konsumen atas dasar preferensi konsumen. Penelitian mengenai preferensi konsumen yang dilakukan di Indonesia dilakukan oleh Bainana et al. (2013) dengan judul Identifikasi Preferensi Konsumen dalam Minat Beli Rumah dengan pendekatan Metode Decision Tree. Tujuan dari penelitian tersebut adalah untuk mengetahui berbagai keinginan konsumen dalam membeli suatu hunian. Sementara itu, preferensi konsumen dalam minat beli rumah ditentukan oleh kedekatan lokasi dengan fasilitas di sekitar perumahan, ketersediaan bentuk pagar perumahan, fasilitas keamanan, bentuk pembayaran rumah, ketersediaan fasilitas air, bentuk jalanan perumahan, dan model rumah (Bainana et al. 2013). 
Studi mengenai keputusan pembelian hunian ramah lingkungan menjadi pembahasan menarik dalam penelitian ini. Penelitian-penelitian mengenai keputusan pembelian perumahan telah banyak dilakukan, baik di dalam negeri maupun di luar negeri. Atribut paling penting bagi produk perumahan adalah jumlah kamar tidur, luas tanah, type rumah, desain dan jumlah kamar mandi (Tambunan 2009). Hal ini menggambarkan bahwa konsumen pada masa sekarang menyukai produk yang fungsional, berkualitas dan praktis. Kemudian terdapat penelitian mengenai faktorfaktor apa saja yang menentukan seorang konsumen mengambil keputusan untuk membeli perumahan, penelitian yang dilakukan oleh Brahmanto (2011) menunjukkan bahwa faktor-faktor yang mempengaruhi keputusan pembelian konsumen antara lain: 1) citra (image) pengembang; 2) lingkungan; 3) layanan pengembang; dan 4) kualitas bangunan. Dalam penelitian ini, akan digali lebih dalam lagi mengenai persepsi dan preferensi konsumen terhadap keputusan pembelian green product hunian.

Tujuan dari penelitian ini adalah 1) Menganalisis faktor yang mempengaruhi persepsi konsumen terhadap keputusan pembelian green product hunian; 2) Menganalisis faktor yang mempengaruhi preferensi konsumen terhadap keputusan pembelian green product hunian, 3) Menganalisis pengaruh antara persepsi dan preferensi konsumen terhadap keputusan pembelian green product hunian; dan 4) Memformulasikan model keputusan pembelian green product hunian .

\section{Metode Penelitian}

Penelitian dilakukan di wilayah hunian Puri Botanical Residence dan wilayah sekitar hunian tersebut di daerah Jakarta Barat. Contoh yang digunakan dibagi menjadi dua kelompok, yaitu kelompok penghuni dan kelompok non-penghuni. Responden kelompok penghuni adalah orang-orang yang tinggal di Puri Botanical Residence, sementara kelompok non-penghuni adalah orang-orang yang tinggal di wilayah sekitar Puri Botanical Residence. Total responden baik yang merupakan kelompok penghuni dan kelompok non-penghuni berjumlah 151 responden, pembagiannya adalah sebanyak 99 responden merupakan kelompok penghuni dan 52 responden merupakan kelompok non-penghuni. Pengambilan data dilaksanakan sejak bulan Januari sampai April 2014.

Dalam penelitian ini digunakan Desain Cross-Sectional, dimana pengumpulan informasi dari setiap elemen populasi contoh dilakukan hanya sekali pada waktu tertentu. Kemudian, peneliti melakukan survei yaitu suatu desain penelitian yang mengumpulkan data dari sejumlah contoh responden yang dipilih dari sebuah populasi. Data dikumpul dengan menggunakan instrumen kuesioner. Kuesioner disusun secara terstruktur.

Pada saat survei dilakukan, teknik penentuan contoh dilakukan dengan convenience sampling yaitu teknik contoh non-probabilitas dimana subyek dipilih karena aksesibilitas nyaman dan kedekatan mereka kepada peneliti (Sumarwan 2011). Dengan menuju kepada konsumen selaku pembeli dan penghuni di Puri Botanical Residence, dan juga pembeli potensial yaitu masyarakat yang tinggal di wilayah sekitar, diharapkan dapat mewakili populasi. 
Analisis deskriptif adalah metode penelitian yang meliputi pengumpulan data dalam rangka melakukan pengujian terhadap suatu hipotesa atau menjawab suatu pertanyaan. Penggunaan analisis deskriptif bertujuan untuk mengelompokkan jawaban yang sama agar mudah dipahami. Dalam penelitian ini analisis deskriptif mencakup demografi responden dengan melihat presentase dari jawaban hasil penyebaran kuesioner.

Analisis Partial Least Squares (PLS) merupakan teknik statistika multivariat yang melakukan perbandingan antara variabel dependen berganda dan variabel independen berganda. PLS adalah salah satu metoda statisika Structural Equation Modelling berbasis varian yang didesain untuk menyelesaikan permasalahaaan struktural yang melibatkan banyak variabel atau konstruk banyak ketika ukuran contoh penelitiaan kecil, adanya data yang hilang atau missing values multikolinearitas. PLS telah diuji coba pada data riil dan dalam simulasi (Garthwaite 1994). Analisis PLS digunakan untuk mengetahui apakah terdapat pengaruh dari faktor-faktor persepsi dan preferensi konsumen terhadap keputusan pembelian green product hunian.

Masing-masing indikator yang dianggap mewakili variabel tersebut diukur dengan angka dari skala Likert 1-5, dimana 1 adalah sangat tidak setuju, 2 adalah tidak setuju, 3 adalah cukup setuju, 4 adalah setuju dan 5 adalah sangat setuju. Variabel dalam penelitian ini terdiri atas variabel laten eksogen dan variabel laten endogen. Data yang diperlukan untuk variabel-variabel operasional harus berdasarkan kerangka konseptual yang dikembangkan. Variabel laten eksogen terdiri dari sebelas konsutruk yaitu lokasi, produk, harga, promosi, fasilitas, citra pengembang, faktor sosial, metode pembayaran, pengaruh lingkungan, persepsi konsumen dan preferensi konsumen. Sedangkan variabel laten endogen terdiri dari keputusan pembelian. Uraian rinci dari keseluruhan variabel yang digunakan dalam penelitian ini diuraikan pada Tabel 1.

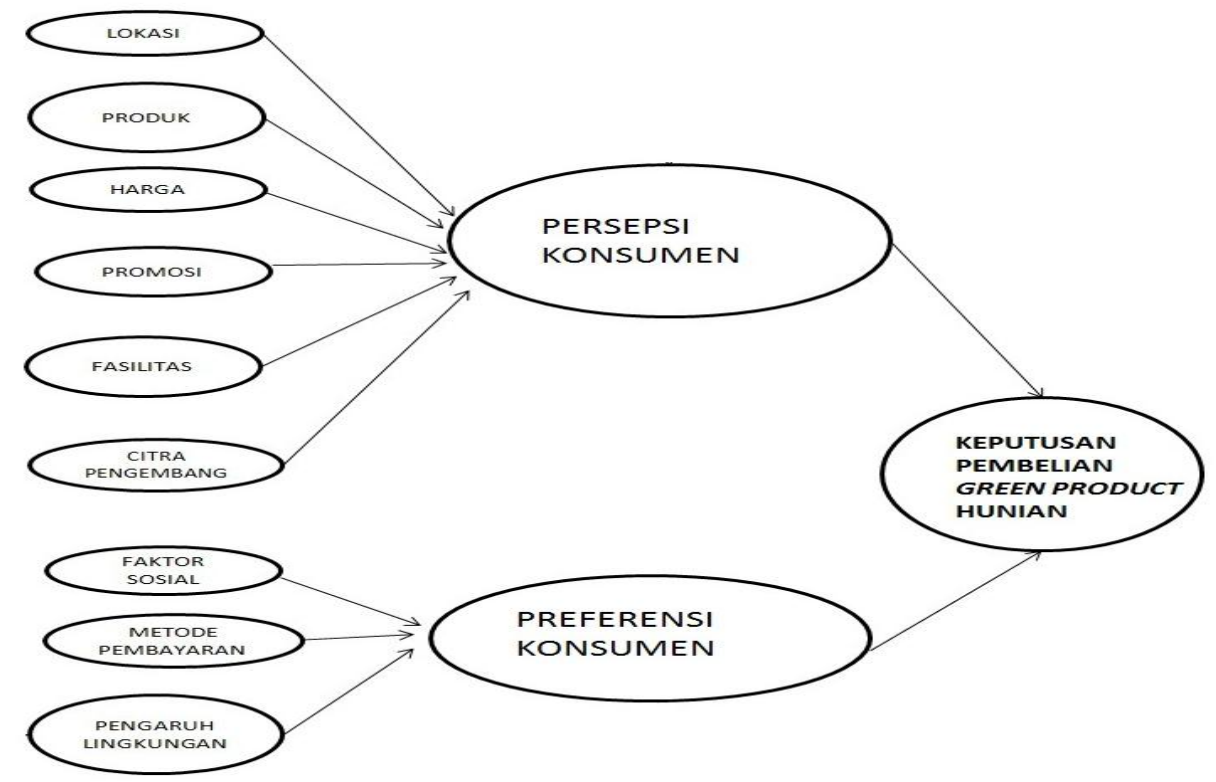

Gambar 1. Kerangka pemikiran konseptual 
Berdasarkan kerangka pemikiran yang telah dijelaskan di atas, maka dapat disusun hipotesis yang akan digunakan dalam penelitian ini sebagai berikut:

H1 : Faktor lokasi diduga ada pengaruh signifikan terhadap persepsi konsumen.

$\mathrm{H} 2$ : Faktor produk diduga ada pengaruh signifikan terhadap persepsi konsumen.

H3 : Faktor harga diduga ada pengaruh signifikan terhadap persepsi konsumen.

H4 : Faktor promosi diduga ada pengaruh signifikan terhadap persepsi konsumen.

H5 : Faktor fasilitas diduga ada pengaruh signifikan terhadap persepsi konsumen.

H6 : Faktor citra pengembang diduga ada pengaruh signifikan terhadap persepsi konsumen.

H7 : Faktor sosial diduga ada pengaruh signifikan terhadap preferensi konsumen.

H8 : Faktor metode pembayaran diduga ada pengaruh signifikan terhadap preferensi konsumen.

H9 : Faktor pengaruh lingkungan diduga ada pengaruh signifikan terhadap preferensi konsumen.

H10 : Persepsi konsumen diduga ada pengaruh signifikan terhadap keputusan pembelian green product hunian .

H11 : Preferensi konsumen diduga ada pengaruh signifikan terhadap keputusan pembelian green product hunian

Definisi operasional pada penelitian merupakan unsur penelitian yang terkait dengan variabel yang terdapat dalam penelitian sesuai dengan hasil perumusan masalah. Definisi operasional dalam penelitian ini dirinci pada Tabel 1 dan dijelaskan sebagai berikut:

1. Lokasi

Lokasi merupakan suatu tempat dimana green product hunian Puri Botanical Residence berada. Pada lokasi ini, Puri Botanical Residence berada di lokasi yang bersih dan bebas polusi (X1), bebas banjir (X2) dan dekat dengan sarana umum (X3).

2. Produk

Segala sesuatu yang ditawarkan ke pasar untuk mendapatkan perhatian, dibeli, digunakan, atau dikonsumsi yang dapat memuaskan keinginan atau kebutuhan (Kotler dan Amstrong 2008). Puri Botanical Residence merupakan green product hunian, sehingga konsep yang ditawarkan adalah hunian berupa produk yang ramah lingkungan (X4) dan konsep yang sustainable (X5)

3. Harga

Harga merupakan satuan moneter atau ukuran lainnya (termasuk barang dan jasa lainnya) yang ditukarkan agar memperoleh hak kepemilikan atau penggunaan suatu barang atau jasa (Tjiptono 2008). Dalam lingkup penelitian ini, persepsi harga yang ingin diteliti adalah mengenai kemampuan konsumen membayar sejumlah harga (X6), ketelitian konsumen mencari informasi harga sebelum pembelian (X7), dan persepsi konsumen mengenai harga jual kembali (X8).

4. Promosi

Menurut Perreault et al. (2009) promosi adalah mengomunikasikan informasi antara penjual dan pembeli potensial atau orang lain dalam saluran untuk memengaruhi sikap dan perilaku. Persepsi konsumen mengenai promosi dalam penelitian ini adalah frekuensi konsumen melihat iklan di media (X9), peran 
wiraniaga dalam pameran (X10), dan persepsi konsumen mengenai acara customer gathering yang diadakan oleh PT. Copylas Indonesia di Puri Botanical Residence (X11).

5. Fasilitas

Fasilitas merupakan sesuatu yang dapat membantu memudahkan pekerjaan, tugas, dan sebagainya. Oleh karena itu, untuk memenuhi kebutuhan konsumen, PT. Copylas Indonesia menyediakan beragam fasilitas. Dalam melihat persepsi konsumen atas fasilitas yang diberikan oleh PT. Copylas Indonesia, maka penelitian ini melihat persepsi konsumen terhadap fasilitas yang diberikan, yaitu: fasilitas keamanan (X12), taman botani (X13), dan listrik, Telepon dan PDAM (X14).

Tabel 1. Variabel yang digunakan dalam penelitian

\begin{tabular}{|c|c|c|c|}
\hline No & Variabel Laten & Simbol Laten & Variabel Eksogen \\
\hline 1. & Lokasi & $\xi 1$ & $\begin{array}{l}\text { X1= Lokasi perumahan bersih dan bebas polusi } \\
\text { X2= Lokasi perumahan bebas banjir } \\
\text { X3= Lokasi perumahan dekat dengan sarana umum } \\
\text { (sekolah, tempat peribadatan, olah raga, dll). }\end{array}$ \\
\hline 2. & Produk & $\xi 2$ & $\begin{array}{l}X 4=\text { Produk ramah lingkungan } \\
X 5=\text { Konsep bangunan sustainable }\end{array}$ \\
\hline 3. & Harga & $\xi 3$ & $\begin{array}{l}\text { X6= Kemampuan konsumen membayar sejumlah harga } \\
\text { X7=Ketelitian mencari informasi harga sebelum } \\
\text { pembelian } \\
\text { X8= Harga jual kembali }\end{array}$ \\
\hline 4. & Promosi & $\xi 4$ & $\begin{array}{l}\mathrm{X} 9=\text { Frekuensi konsumen melihat iklan di media } \\
\mathrm{X} 10=\text { Peran wiraniaga dalam pameran } \\
\mathrm{X} 11=\text { Customer gathering }\end{array}$ \\
\hline 5. & Fasilitas & $\xi 5$ & $\begin{array}{l}\text { X12 = Fasilitas Keamanan } \\
\text { X13= Taman botani } \\
\text { X14= Listrik, Telpon dan PDAM }\end{array}$ \\
\hline 6. & $\begin{array}{l}\text { Citra } \\
\text { Pengembang }\end{array}$ & $\xi 6$ & $\begin{array}{l}X 15=\text { Memperhatikan komplain konsumen } \\
\text { X16= Janji pihak pengembang dalam memenuhi fasilitas }\end{array}$ \\
\hline 7. & Faktor Sosial & ६8 & $\begin{array}{l}\text { X17= Mengumpulkan informasi dari keluarga } \\
\text { X18= Mengumpulkan informasi dari ahli kesehatan }\end{array}$ \\
\hline 8. & $\begin{array}{l}\text { Metode } \\
\text { Pembayaran }\end{array}$ & $\xi 10$ & $\begin{array}{l}\text { X19=Fasilitas pembayaran yang diberikan oleh } \\
\text { pengembang } \\
\text { X20= Jangka waktu pembayaran } \\
\text { X21= Suku bunga }\end{array}$ \\
\hline 9. & $\begin{array}{l}\text { Pengaruh } \\
\text { Lingkungan }\end{array}$ & ६11 & $\begin{array}{l}\text { X22= Lingkungan asri } \\
\text { X23= Lingkungan sehat }\end{array}$ \\
\hline 10. & $\begin{array}{l}\text { Persepsi } \\
\text { Konsumen }\end{array}$ & $\eta_{1}$ & $\begin{array}{l}\mathrm{Y} 1=\text { Menunjukkan status sosial } \\
\mathrm{Y} 2=\text { Menunjukkan kesuksesan, prestise } \& \text { kekayaan }\end{array}$ \\
\hline \multirow[t]{2}{*}{11.} & $\begin{array}{l}\text { Preferensi } \\
\text { Konsumen }\end{array}$ & $\eta_{2}$ & $\begin{array}{l}\text { Y3= Desain rumah new modern tropical } \\
\text { Y4=Desain rumah modern minimalis sesuai harapan } \\
\text { konsumen }\end{array}$ \\
\hline & & & Variabel Endogen \\
\hline 12. & $\begin{array}{l}\text { Keputusan } \\
\text { Pembelian } \\
\text { green product } \\
\text { hunian (Y) }\end{array}$ & & $\begin{array}{l}\text { Y5=Mencari informasi sebanyak-banyaknya mengenai } \\
\text { hunian } \\
\text { Y6= Membeli hunian di PBR dalam 1-2th mendatang } \\
\text { Y7= Merekomendasikan pihak lain untuk membeli }\end{array}$ \\
\hline
\end{tabular}


6. Citra Pengembang

Citra merupakan hasil evaluasi dalam diri seseorang berdasarkan persepsi dan pemahaman terhadap gambaran yang telah diolah, diorganisasikan, dan disimpan dalam benak seseorang. Variabel citra pengembang adalah hasil evaluasi atau gambaran mengenai PT. Copylas Indonesia dilihat dari persepsi konsumen. Dalam penelitian ini, persepsi konsumen terhadap citra pengembang adalah memperhatikan keluhan (complaint) konsumen (X15) dan janji pihak pengembang dalam memenuhi fasilitas (X16).

7. Faktor Sosial

Preferensi konsumen dari faktor sosial dalam penelitian ini adalah bagaimana orang-orang disekitar konsumen mempengaruhi konsumen terhadap keputusan pembelian, yaitu dengan memberikan informasi kepada konsumen mengenai hunian tersebut. Adapun informasi yang dikumpulkan bersumber dari keluarga (X17) dan informasi dari teman, lingkungan kerja, dan lain-lain (diluar keluarga) (X18).

8. Metode Pembayaran

Metode pembayaran merupakan cara-cara melakukan pembayaran. Preferensi konsumen terhadap metode pembayaran adalah melihat fasilitas pembayaran yang diberikan oleh pengembang (X19), jangka waktu pembayaran (X20), dan suku bunga yang ditawarkan oleh pengelola hunian (X21).

9. Pengaruh Lingkungan

Lingkungan merupakan bagian terpenting dan mendasar dari kehidupan manusia, sehingga lingkungan sekitar dalam kawasan hunian dapat dijadikan preferensi bagi konsumen atas keputusan pembelian hunian. Dalam penelitian ini, persepsi konsumen terhadap pengaruh lingkungan adalah tersedianya lingkungan yang asri (X22) dan lingkungan perkotaan (X23).

10. Keputusan pembelian

Terkait dengan keputusan pembelian yang dilakukan oleh konsumen, peneliti ingin mengetahui apakah konsumen akan mencari informasi sebanyak-banyaknya terkait dengan green product hunian di Puri Botanical Residence (Y5), apakah konsumen akan melakukan pembelian green product hunian di Puri Botanical Residence dalam waktu satu sampai dua tahun mendatang (Y6), dan apakah konsumen akan merekomendasikan kepada pihak lain untuk membeli green product hunian di Puri Botanical Residence (Y7).

\section{Hasil dan Pembahasan}

III.1. Profil Responden

Responden dalam penelitian ini adalah penghuni di Puri Botanical Residence dan non-penghuni, dimana non-penghuni adalah masyarakat yang tinggal di sekitar Puri Botanical Residence dan mengetahui lokasi Puri Botanical Residence. Jumlah responden adalah 151 responden. Profil pengisi kuisioner dijelaskan berdasarkan usia, jenis kelamin, status pernikahan, jumlah anggota keluarga inti, pendidikan akhir, pekerjaan, pengeluaran dan kota tempat bekerja. 
Responden dibagi menjadi dua bagian, yaitu 99 responden (65.6\%) merupakan kelompok penghuni dan 52 responden (34.4\%) merupakan kelompok non penghuni di Puri Botanical Residence. Rincian profil responden dapat dilihat pada Tabel 2.

Tabel 2. Profil responden

\begin{tabular}{|c|c|c|c|c|c|}
\hline \multirow[t]{2}{*}{ Karakteristik } & \multirow[t]{2}{*}{ Kategori } & \multicolumn{2}{|c|}{ Penghuni } & \multicolumn{2}{|c|}{ Non Penghuni } \\
\hline & & $\mathbf{N}$ & $\%$ & $\mathbf{N}$ & $\%$ \\
\hline \multirow[t]{5}{*}{ Usia } & 25th - 34th & 29 & 29.30 & 22 & 42.3 \\
\hline & 35th - 44th & 41 & 41.40 & 12 & 23.1 \\
\hline & 45th - 54th & 29 & 29.30 & 4 & 7.7 \\
\hline & $>55$ th & - & - & 14 & 27.00 \\
\hline & Total & 99 & 100.00 & 52 & 100.00 \\
\hline \multirow[t]{3}{*}{ Jenis Kelamin } & Laki laki & 51 & 51.50 & 20 & 38.50 \\
\hline & Perempuan & 48 & 48.50 & 32 & 61.50 \\
\hline & Total & 99 & 100.00 & 52 & 100.00 \\
\hline \multirow[t]{4}{*}{ Status Pernikahan } & Belum Menikah & - & - & 16 & 30.80 \\
\hline & Menikah & 99 & 100.00 & 34 & 65.40 \\
\hline & Duda/Janda & - & - & 2 & 3.80 \\
\hline & Total & 99 & 100.00 & 52 & 100.00 \\
\hline \multirow[t]{3}{*}{ Jumlah Keluarga } & 2-4 Orang & 95 & 96.00 & 50 & 96.20 \\
\hline & $>5$ Orang & 4 & 4.00 & 2 & 3.80 \\
\hline & Total & 99 & 100.00 & 52 & 100.00 \\
\hline Pendidikan & SMU & - & - & 2 & 3.80 \\
\hline \multirow[t]{4}{*}{ Terakhir } & Diploma & 25 & 25.30 & 4 & 7.70 \\
\hline & S1 & 57 & 57.60 & 34 & 65.40 \\
\hline & $\mathrm{S} 2$ & 17 & 17.20 & 12 & 23.10 \\
\hline & Total & 99 & 100.00 & 52 & 100.00 \\
\hline \multirow[t]{6}{*}{ Pekerjaan } & Wiraswasta & 25 & 25.30 & 8 & 15.40 \\
\hline & Pegawai Negeri & 3 & 3.00 & 6 & 11.50 \\
\hline & Pegawai Swasta & 40 & 40.40 & 16 & 30.80 \\
\hline & Ibu Rumah Tangga & 31 & 31.30 & 14 & 26.90 \\
\hline & Pegawai BUMN & - & - & 8 & 15.40 \\
\hline & Total & 99 & 100.00 & 52 & 100.00 \\
\hline \multirow[t]{6}{*}{$\begin{array}{l}\text { Pengeluaran } \\
\text { Bulanan }\end{array}$} & Rp 700001 sd Rp 1000000 & 7 & 7.10 & 10 & 19.23 \\
\hline & Rp 1000001 sd Rp 1500000 & 6 & 6.10 & 18 & 34.62 \\
\hline & Rp 1500001 sd Rp 2000000 & 9 & 9.10 & 4 & 7.70 \\
\hline & Rp 2000001 sd Rp 3000000 & 16 & 16.20 & 2 & 3.85 \\
\hline & > Rp 3000000 & 61 & 61.50 & 18 & 34.60 \\
\hline & Total & 99 & 100.00 & 52 & 100.00 \\
\hline \multirow{4}{*}{$\begin{array}{l}\text { Kota Tempat } \\
\text { Beraktivitas/ } \\
\text { bekerja }\end{array}$} & DKI Jakarta & 95 & 96.00 & 46 & 88.50 \\
\hline & Tangerang & 2 & 2.00 & 6 & 11.50 \\
\hline & Bekasi & 2 & 2.00 & - & - \\
\hline & Total & 99 & 100.00 & 52 & 100.00 \\
\hline
\end{tabular}

\section{III.2. Evaluasi Pengukuran (Outer) Model}

Suatu konsep dalam model penelitian tidak dapat diuji bila dalam model prediksi terdapat hubungan relasional dan kausal yang belum melewati tahap purifikasi dalam model pengukuran. Model pengukuran tersebut digunakan untuk menguji validitas konstruk dan reliabilitas instrumen. Hair et al. (2006) menjelaskan bahwa rule of 
54|Wardhani, Sumarwan, Yuliati - Pengaruh Persepsi dan Preferensi Konsumen

thumb yang biasanya digunakan untuk membuat pemeriksaan awal dari faktor muatan adalah $\geq 0.3$ telah memenuhi level minimal faktor muatan $\geq 0.4$ dianggap lebih baik dan untuk faktor muatan $\geq 0.50$ dianggap signifikan. Semakin tinggi nilai faktor muatan yang ditetapkan, semakin penting peranan loading dalam menginterpretasikan matriks faktor.

Tabel 3. Nilai AVE, communality, Cronbach's alpha dan composite reliability

\begin{tabular}{lcccc}
\hline \multicolumn{1}{c}{ Atribut } & AVE & Communality & Cronbach's alpha & Composite Reliability \\
\hline Lokasi & 0.418 & 0.418 & 0.338 & 0.682 \\
Produk & 0.927 & 0.927 & 0.926 & 0.962 \\
Harga & 0.917 & 0.917 & 0.955 & 0.971 \\
Promosi & 0.594 & 0.594 & 0.683 & 0.811 \\
Fasilitas & 0.534 & 0.534 & 0.590 & 0.772 \\
Citra Pengembang & 0.742 & 0.742 & 0.654 & 0.852 \\
Faktor Sosial & 0.625 & 0.625 & 0.482 & 0.758 \\
Metode Pembayaran & 0.810 & 0.810 & 0.886 & 0.927 \\
Pengaruh Lingkungan & 0.870 & 0.870 & 0.853 & 0.930 \\
Persepsi Konsumen & 0.867 & 0.867 & 0.847 & 0.929 \\
Preferensi Konsumen & 0.849 & 0.849 & 0.822 & 0.918 \\
Keputusan Pembelian & 0.678 & 0.678 & 0.765 & 0.863 \\
\hline
\end{tabular}

Menurut Chin (1995) rule of thumb yaang digunakaan untuk validitas konvergen adalah outer loading $>0.7$; communality $>0.5$; dan average variance extracted (AVE) > 0.5. Berdasarkan rule of thumbs yang mengikuti Hair et al. (2006), yaitu nilai faktor muatan $\geq 0.4$ dianggap lebih baik, karena dari model pengukuran tidak terdapat satu indikatorpun dengan nilai faktor muatan $<0.4$ sehingga tidak ada indikator yang harus dibuang dari model. Tahapan selanjutnya adalah melihat hasil dari nilai average variance extracted (AVE) dan communality pada setiap atribut untuk melakukan uji validitas. Hasil kedua nilai tersebut memenuhi syarat yakni $\geq 0.5$ (Hair et al. 2006) akan tetapi ada satu atribut yakni atribut lokasi dimana nilai AVE maupun communality nya 0.418. Apabila terdapat atribut yang menghasilkan nilai AVE dan communality nya di bawah 0.5 menandakan bahwa atribut tersebut validitasnya rendah dan hal ini menjadi keterbatasan penelitian untuk atribut tersebut. AVE mengukur validitas instrumen atau pertanyaan pada kuesioner, misal peneliti ingin mengukur tinggi tetapi oleh responden dijawab atau ditafsirkan panjang.

PLS digunakan untuk menguji reliabilitas untuk mengukur konsistensi internal alat ukur. Reliabilitas menunjukkan akurasi, konsistensi dan ketepatan suatu alat ukur. Uji reliabilitas dalam PLS menggunaakan dua metode, yaaitu Cronbach's alpha dan composite reliability. Menurut Hair et al. (2006) rule of thumb nilai alpha atau composite reliability harus lebih besar dari 0.7 meskipun nilai 0.6 masih dapat diterima. Namun sesungguhnya uji konsistensi internal tidak mutlak untuk dilakukan jika validitas konstruk telah terpenuhi, karena konstruk yang valid adalah konstruk yang reliabel, sebaliknya konstruk yang reliabel belum tentu valid (Cooper dan Schindler 2006).

Nilai Cronbach's alpha dan composite reliability, yaitu dengan hasil olah data yang menyebutkan bahwa terdapat tiga variabel dengan nilai Cronbach's alpha di bawah 0.6 dan sembilan pengukur dalam penelitian ini yaitu produk, harga, promosi, citra pengembang, metode pembayaran, pengaruh lingkungan, persepsi konsumen, 
preferensi konsumen dan keputusan pembelian memiliki nilai Cronbach's alpha di atas 0.6. Sementara pada nilai composite reliability seluruh variabel hasilnya di atas 0.6. Menurut Chin (1995), Cronbach's alpha mengukur batas bawah nilai reliabilitas suatu konstruk sedangkan composite reliability mengukur nilai sesungguhnya reliabilitas suatu konstruk. Namun, composite reliability dinilai lebih baik dalam mengestimasi konsistensi internal suatu konstruk (Salisbury et al. 2002). Oleh karena itu, berdasarkan ungkapan teori sebelumnya dapat dikatakan bahwa seluruh pengukur yang dipakai dalam penelitian ini adalah reliable. Tabel 3 di atas menunjukkan nilai AVE, communality, Cronbach's alpha dan composite reliability.

\section{III.3. Evaluasi Pengukuran (Inner) Model}

Model struktural dalam PLS dievaluasi dengan menggunakan $R$-square untuk variabel dependen dan nilai koefisien pada path $(\beta)$ untuk variabel independen yang kemudian dinilai signifikansinya berdasarkan nilai $t$-statistic setiap path. Tabel 4 di bawah ini menunjukkan nilai $R$-square untuk variabel dependen.

\begin{tabular}{lc} 
Tabel 4. Nilai R-square (R2) & \\
\hline Konstruk Dependen & R-square \\
\hline Persepsi Konsumen & 0.205 \\
Preferensi Konsumen & 0.214 \\
Keputusan Pembelian & 0.163 \\
\hline
\end{tabular}

Berdasarkan Tabel 4 dihasilkan nilai $R$-square untuk variabel persepsi konsumen sebesar 0.205 yang artinya bahwa variasi persepsi konsumen dapat dijelaskan oleh variabel konstruk lokasi, produk, harga, promosi, fasilitas, dan citra pengembang sebesar $20.5 \%$ sedangkan sisanya yaitu sebesar $79.5 \%$ dipengaruhi oleh variabel lain yang tidak terdapat dalam model penelitian. Menurut Dahmiri (2010), faktor persepsi konsumen yang mempengaruhi pembelian rumah antara lain harga rumah, sistem pembelian, model atau tipe rumah, kualitas rumah, dan lokasi rumah. Sedangkan menurut Anastasia (2013), pemetaan persepsi konsumen terhadap atribut-atribut rumah tinggal yang diminati yaitu lingkungan, lokasi, harga, dan fisik. Lebih mendalam lagi, atribut fisik mencakup model rumah, luas tanah, luas bangunan, fasilitas eksterior dan fasilitas interior. Sementara itu menurut Tanata (2013), faktor yang mempengaruhi persepsi konsumen dalam pembelian rumah antara lain kinerja, pelayanan, ketahanan, keandalan, karakteristik produk, kesesuaian dengan spesifikasi, dan hasil. Berdasarkan hal tersebut dapat disimpulkan bahwa variabel konstruk lokasi, produk, harga, promosi, fasilitas, dan citra pengembang hanya mampu menjelaskan $20.5 \%$ sebagai faktor persepsi konsumen, sedangkan $79.5 \%$ dijelaskan oleh variabel kualitas rumah, fisik rumah, ketahanan, keandalan, dan kesesuaian dengan spesifikasi.

Pada variabel preferensi konsumen dihasilkan $R$-square sebesar 0.214 , artinya bahwa variasi preferensi konsumen dapat dijelaskan oleh variabel konstruk faktor sosial, metode pembayaran dan pengaruh lingkungan sebesar $21.4 \%$ sedangkan sisanya yaitu sebesar $78.6 \%$ dipengaruhi oleh variabel lain yang tidak terdapat dalam model penelitian. Menurut Bainana et al. (2013) dalam penelitiannya mengemukakan bahwa terdapat tujuh faktor yang mempengaruhi preferensi konsumen dalam keputusan pembelian rumah, antara lain kedekatan lokasi dengan fasilitas disekitar perumahan, ketersediaan bentuk pagar perumahan, fasilitas keamanan, bentuk 
pembayaran rumah, ketersediaan fasilitas air, bentuk jalan perumahan, dan model rumah. Sementara itu dalam penelitian yang dilakukan oleh Arianty dan Rohmana (2012) menyatakan bahwa anggaran dan atribut produk berpengaruh positif dan signifikan mempengaruhi preferensi konsumen terhadap suatu keputusan pembelian. Berdasarkan hal tersebut dapat disimpulkan bahwa variabel konstruk faktor sosial, metode pembayaran dan pengaruh lingkungan hanya mampu menjelaskan $20.8 \%$ sebagai faktor preferensi konsumen, sedangkan $78.6 \%$ dipengaruhi oleh variabel kedekatan lokasi dengan fasilitas disekitar perumahan, ketersediaan bentuk pagar perumahan, bentuk jalan perumahan, dan anggaran.

Pada variabel keputusan pembelian dihasilkan $R$-square sebesar 0.163 , artinya bahwa variasi keputusan pembelian dapat dijelaskan oleh variabel konstruk persepsi konsumen dan preferensi konsumen sebesar $16.3 \%$ sedangkan sisanya yaitu sebesar 83.7\% dipengaruhi oleh variabel lain yang tidak terdapat dalam model penelitian. Menurut Listyorini (2012), perubahan lingkungan yang dinamis menyebabkan studi gaya hidup konsumen dapat membantu pemasar memahami bagaimana konsumen berpikir dan memilih berbagai alternatif. Sugito (2004) memaparkan dalam penelitiannya bahwa faktor-faktor yang mempengaruhi perilaku konsumen terhadap keputusan pembelian rumah antara lain harga, tingkat pendapatan, cara pembayaran, motivasi, promosi, fasilitas, lokasi, lingkungan, desain, luas lahan dan bangunan. Sedangkan menurut Galaty (2006) dengan adanya perkembangan informasi dan perbaikan tingkat ekonomi, pengetahuan dan gaya hidup di masyarakat, maka penentuan dalam pemilihan perumahan di masyarakat mengalami perkembangan, terutama pada masyarakat kalangan menengah ke atas. Berdasarkan hal tersebut dapat disimpulkan bahwa variabel konstruk persepsi konsumen dan preferensi konsumen hanya mampu menjelaskan $16.3 \%$ sebagai faktor keputusan pembelian, sedangkan $83.7 \%$ dipengaruhi oleh variabel gaya hidup, motivasi, tingkat pendapatan, perkembangan informasi, perbaikan tingkat ekonomi dan pengetahuan.

Berdasarkan nilai $R$-square yang dihasilkan di atas disimpulkan bahwa variabel persepsi konsumen dapat dijelaskan oleh variabel konstruk sebesar $20.5 \%$, variabel preferensi konsumen dijelaskan oleh variabel konstruk sebesar $21.4 \%$ dan variabel keputusan pembelian green product hunian dapat dijelaskan oleh variabel konstruk sebesar 16.3\%. Menurut Jogiyanto (2011), R-square bukanlah parameter absolut dalam mengukur ketepatan model prediksi karena dasar hubungan teoritis adalah parameter yang paling utama untuk menjelaskan hubungan kausalitas tersebut.

\section{III.4. Pengaruh Persepsi dan Preferensi Konsumen terhadap Keputusan Pembelian} Green Product hunian.

Untuk menilai signifikansi model prediksi dalam pengujian model struktural, dapat melihat pada nilai $t$-statistic antara variabel independen ke variabel dependen. Menurut Hartono (2008), ukuran signifikansi keterdukungan hipotesis dapat digunakan perbandingan $t$-table dan $t$-statistic. Jika nilai $t$-statistic lebih tinggi dibandingkan dengan nilai $t$-table, berarti hipotesis terdukung. Untuk tingkat keyakinan $95 \%$ (alpha $5 \%)$ maka nilai $t$-table untuk hipotesis satu arah adalah $\geq 1.64$. Batas untuk menolak dan menerima hipotesis yang diajukan adalah $\geq 1.64$, dimana apabila nilai $t$ berada pada nilai < 1.64 maka hipotesis akan ditolak atau dengan kata lain menerima hipotesis nol (HO). Gambar 2 menunjukkan uji signifikansi model pengukuran pada penelitian ini. 
Berdasarkan Gambar 2 dapat dilihat hasil perhitungan menunjukkan bahwa faktor lokasi, harga, dan promosi terhadap persepsi konsumen tidak berpengaruh secara signifikan. Sementara faktor produk, fasilitas dan citra pengembang terhadap persepsi konsumen berpengaruh secara signifikan. Apabila faktor produk, fasilitas dan citra pengembang meningkat, maka cenderung akan meningkatkan persepsi konsumen terhadap keputusan pembelian green product hunian. Dalam hal ini perusahaan perlu memerhatikan apa yang menjadi kebutuhan dan keinginan konsumen, agar dapat meningkatkan kualitas produk, menyediakan fasilitas lain yang bermanfaat bagi konsumen dan meningkatkan kepercayaan konsumen dari kualitas pelayanan yang diberikan oleh pengembang.

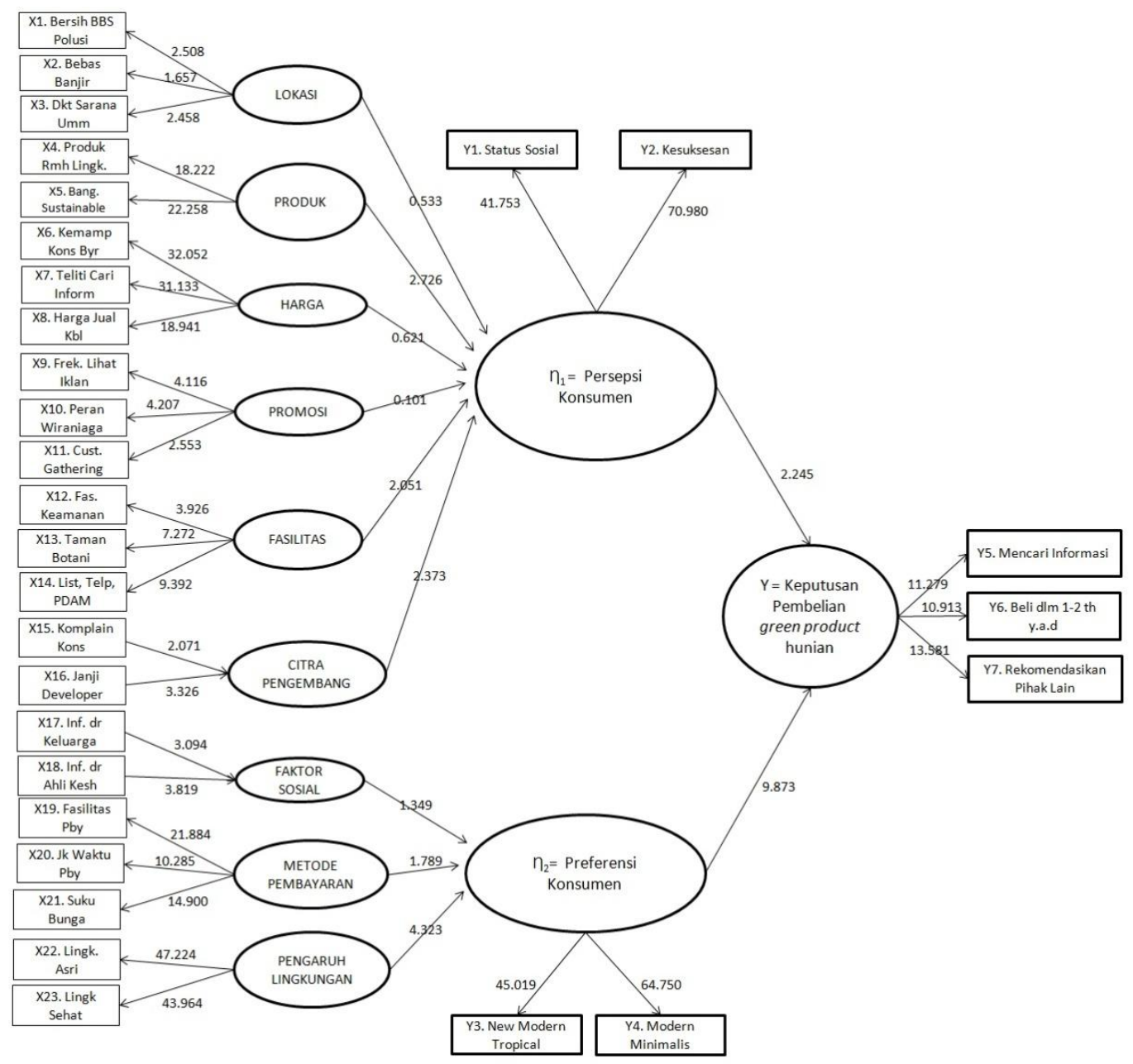

Gambar 2. Uji signifikansi (uji-t) model

Rustandi (2012) menyatakan bahwa produk mempengaruhi persepsi, selain itu Tjiptono (2008) menyatakan bahwa dasar pengambilan keputusan pembelian dapat dilihat melalui atribut produk. Kondisi ini dapat terjadi karena responden memiliki pemahaman mengenai produk ramah lingkungan yang ditawarkan ataupun kriteria bangunan-bangunan yang sustainable. Misalnya konsumen sudah memiliki pengetahuan mengenai kriteria hunian ramah lingkungan yaitu material hunian dekat dengan alam, seperti bata, tanah, kayu, dan lainnya; tersedia taman pada setiap rumah 
dengan konsep minimalis; dan memberikan desain rumah yang memperhatikan ventilasi udara. Mengenai fasilitas, Dahmiri (2010) menyatakan bahwa faktor fasilitas merupakan indikator-indikator yang mengukur tingkat persepsi konsumen yang berpengaruh terhadap keputusan pembelian perumahan. Kemudian Dahmiri (2010) menyebutkan bahwa konsumen menyatakan semua fasilitas yang ditawarkan oleh pengelola perumahan tidak begitu penting kecuali fasilitas keamanan 24 jam. Sementara itu mengenai citra pengembang, Gatignon dan Robertson (1986) menyatakan bahwa citra perusahan membantu konsumen memperoleh pemahaman yang lebih baik tentang produk yang ditawarkan oleh perusahan tertentu dan selanjutnya mengurangi ketidakpastian mereka ketika membuat keputusan membeli. Dalam kondisi tersebut konsumen melihat adanya perhatian dari pengembang terkait komplain konsumen tersebut, selain itu konsumen menganggap bahwa janji pihak pengembang terhadap fasilitas yang diberikan yakni sesuai dengan kebutuhan konsumen terlaksana.

Pada faktor lokasi hal ini dapat saja terjadi apabila dalam benak konsumen, konsumen belum melihat bahwa lokasi di dekat kawasan green product hunian bersih, bebas polusi, bebas banjir dan dekat dengan sarana umum. Sementara itu konsumen menginginkan hunian dimana lokasinya bersih, bebas polusi, bebas banjir dan dekat dengan sarana umum. Pada faktor harga, kondisi tersebut dapat terjadi apabila responden dalam penelitian ini tidak hanya melihat tiga indikator terkait dengan atribut harga tersebut. Responden merasa bahwa harga yang beredar di pasaran tidak jauh berbeda dengan harga jual green product hunian, sehingga yang diutamakan responden dalam pemilihan hunian tersebut adalah kenyamanan dan lingkungannya. Sedangkan pada faktor promosi, kondisi tersebut dapat dipahami apabila dalam hal atribut promosi yang telah dilakukan oleh perusahaan tidak mengena kepada konsumen. Beberapa kemungkinan yang terjadi antara lain: 1) frekuensi iklan untuk memberikan konsumen informasi terkait penawaran green product hunian jumlahnya sedikit, sehingga konsumen tidak begitu mengenal hunian tersebut; 2) event customer gathering yang diadakan untuk mempererat hubungan pelanggan dan target pemasar tidak optimal dijalankan, sehingga tidak efektif dalam pemberian informasi; dan 3) peran wiraniaga dalam pameran adalah penting, namun belum efektif. Sewajarnya dalam kesempatan seperti ini, dapat menjaring target pasar yang lebih luas, dapat memahami apa yang dibutuhkan oleh konsumen dan dapat memelihara hubungan yang terjalin dengan konsumen lebih baik lagi.

Pada preferensi konsumen, faktor metode pembayaran dan pengaruh lingkungan secara signifikan mempengaruhi preferensi konsumen terhadap keputusan pembelian green product hunian. Sementara itu, faktor sosial tidak mempengaruhi preferensi konsumen secara signifikan. Alasan pertama, kondisi ini dapat terjadi apabila responden tidak hanya mempertimbangkan pendapat keluarga atau pendapat sang ahli atau pakar ketika melakukan pembelian hunian. Kedua, bisa saja responden mendapat pengaruh dari kelompok acuan lainnya selain keluarga dan pendapat ahli atau pakar seperti sahabat, rekan kerja, komunitas atau kelompok lainnya yang memiliki hubungan erat dengan responden. Ketiga, produk hunian tersebut sudah dipertimbangkan oleh responden tanpa memerlukan pendapat kelompok acuan karena responden sudah mendapatkan banyak informasi terkait hunian tersebut, 
responden dapat mengevaluasi hunian tersebut, dan pihak pengembang mudah dihubungi sehingga responden dapat menggali informasi sebanyak-banyaknya.

Apabila faktor metode pembayaran dan pengaruh lingkungan meningkat, maka cenderung akan meningkatkan persepsi konsumen terhadap keputusan pembelian green product hunian. Bainana et al. (2013) menyebutkan salah satu faktor yang mempengaruhi preferensi konsumen dalam minat beli rumah adalah metode pembayaran. Fasilitas pembayaran, jangka waktu dan suku bunga menarik perhatian konsumen karena dapat membantu memudahkan konsumen untuk memiliki hunian impiannya. Sedangkan keberhasilan perumahan dan permukiman dalam memenuhi kebutuhan penghuninya, dapat diukur dari baik buruknya pelayanan ketersedian infrastruktur minimal (Pratikto 2008). Pelayanan ketersedian infrastruktur minimal terbentuk dari kegiatan komponen-komponen fungsional yang meliputi tiga komponen pokok. yaitu: unsur kodisi fisik dan lingkungan (physycal environment), unsur ketersedian penunjang aktivitas (stock availibility), dan unsur kemudahan mencapai aktivitas (accessibility proximity). Dalam hal ini perusahaan dapat melakukan banyak hal untuk memahami preferensi konsumen terhadap beragam metode pembayaran yang akan mempengaruhi minat beli konsumen dan preferensi konsumen mengenai lingkungan hunian agar bermanfaat pada rencana pembangunan hunian yang akan dilakukan di waktu yang akan datang. Kesimpulan dalam hasil penelitian ini adalah variabel persepsi konsumen dan variabel preferensi konsumen mempengaruhi keputusan pembelian green product hunian.

\section{III.5. Keputusan Pembelian Konsumen}

Tabel 5 menunjukkan nilai dari faktor muatan pada variabel keputusan pembelian. Hasil survei menunjukkan bahwa faktor yang memiliki nilai faktor muatan tertinggi adalah merekomendasikan kepada pihak lain untuk melakukan pembelian yaitu dengan nilai sebesar 0.876 . Peringkat kedua adalah faktor mencari informasi sebanyak-banyaknya mengenai hunian yaitu dengan nilai sebesar 0.807 .

Tabel 5. Uji validitas variabel keputusan pembelian

\begin{tabular}{clcc}
\hline Indikator & \multicolumn{1}{c}{ Atribut } & Loading & T-Hitung \\
\hline Y5 & Mencari informasi sebanyak-banyaknya mengenai hunian & 0.807 & 11.279 \\
Y6 & Membeli hunian di PBR dalam 1-2th mendatang & 0.785 & 10.913 \\
Y7 & Merekomendasikan pihak lain untuk membeli & 0.876 & 13.581 \\
\hline
\end{tabular}

Pada peringkat akhir, melakukan pembelian hunian di Puri Botanical Residence dalam satu hingga dua tahun mendatang dengan nilai sebesar 0.785 . Hal ini dapat disimpulkan bahwa sikap konsumen dalam memutuskan pembelian green product hunian dapat terlihat dari hasil metode PLS terbesar dari sikap mereka dalam merekomendasikan pihak lain untuk membeli. Kondisi di mana baik konsumen yang merupakan penghuni ataupun non-penghuni hendak merekomendasikan hunian Puri Botanical Residence pada pihak lain untuk melakukan pembelian adalah suatu nilai positif yang ditunjukkan oleh konsumen terhadap perusahaan. Hal ini dikarenakan, produk yang ditawarkan, fasilitas yang diberikan dan citra pengembang terhadap pengelolaan hunian tersebut baik untuk diketahui oleh pihak lainnya. 
Konsumen mempertimbangkan untuk melakukan pembelian terhadap hunian tersebut dengan cara mencari informasi sebanyak-banyaknya terkait dengan semua faktor dalam persepsi dan preferensinya. Kemudian, membeli hunian satu hingga dua tahun mendatang bagi pemasar dapat digunakan sebagai tolak ukur untuk memprediksi apakah konsumen akan melakukan pembelian dalam satu dua tahun mendatang. Bagi konsumen yang telah menghuni Puri Botanical Residence, maka pemasar dapat memberikan informasi lebih detail mengenai berinvestasi di Puri Botanical Residence sehingga dapat memberikan pemahaman sekaligus meningkatkan ketertarikan pada konsumen terhadap hunian tersebut.

Kesimpulannya adalah bahwa green product hunian layak untuk direkomendasikan kepada pihak lain. Adapun hal-hal yang dapat dilakukan oleh perusahaan adalah mendalami perilaku pembelian konsumen lebih dalam, mendalami dan memperhatikan apa yang menjadi kebutuhan dan keinginan konsumen, memberikan layanan prima kepada konsumen, memberikan produk yang diminati konsumen dengan kualitas terbaik dan menarik konsumen dengan program-program lainnya yang bermanfaat agar semakin meluas pasar dari produk hunian ini.

\section{III.6. Implikasi Manajerial}

Penggunaan atribut-atribut dalam penelitian ini mencakup bauran pemasaran 4P (Product, Place, Promotion dan Place) dimana bauran pemasaran tersebut merupakan strategi dasar manajemen pemasaran yang ditetapkan oleh perusahaan dalam memasarkan produknya. Berdasarkan hasil penelitian yang telah di bahas, maka implikasi manajerial yang dapat disampaikan kepada manajemen PT. Copylas Indonesia terkait dengan variabel yang mempengaruhi konstruk persepsi dan preferensi konsumen yaitu:

1. Meningkatkan Nilai Tambah Produk

Meningkatkan nilai tambah pada produk yang ditawarkan adalah dengan tetap memperhatikan material hunian tersebut yang ramah lingkungan dengan penggunaan bata, tanah, kayu, dan lainnya, tersedia taman pada setiap rumah dengan konsep minimalis dan memberikan desain rumah yang memperhatikan ventilasi udara.

2. Strategi Penetapan Harga Sesuai dengan Karakteristik Produk dan Manfaat yang Ditawarkan

Perusahaan dapat menawarkan alternatif pembayaran lainnya yang menarik minat konsumen dan memudahkan konsumen dengan cara yang unik dan berbeda dengan perusahaan lainnya dengan tujuan untuk meningkatkan minat beli konsumen.

3. Menjamin Kesediaan Produk yang Berkualitas Bagi Konsumen

Hal-hal yang dapat dilakukan perusahaan yaitu dengan strategi open house, dimana strategi tersebut dilakukan untuk menciptakan kepercayaan konsumen. Konsumen lebih tertarik untuk mengunjungi langsung lokasi hunian yang ditawarkan sebelum akhirnya mereka memutuskan untuk membeli produk tersebut. Kedua, perusahaan dapat menyediakan pusat edukasi hijau yang terbuka untuk masyarakat sekitar sehingga semakin banyak konsumen yang terjaring dan semakin banyak konsumen mengenal hunian di Puri Botanical Residence. 


\section{Kesimpulan}

Berdasarkan hasil penelitian dan hasil analisis SEM yang telah dilakukan, maka dapat ditarik beberapa kesimpulan sebagai berikut: 1) Dilihat dari sisi persepsi konsumen, dari sebanyak enam variabel struktural yang dianalisis menggunakan metode PLS, variabel persepsi konsumen yang mempengaruhi keputusan pembelian antara lain citra pengembang, produk dan fasilitas; 2) Dilihat dari sisi preferensi konsumen, variabel preferensi konsumen yang mempengaruhi keputusan pembelian antara lain pengaruh lingkungan dan metode pembayaran; dan 3) Penilaian terhadap keputusan pembelian, hasil survei menunjukkan bahwa faktor yang memiliki nilai faktor muatan tertinggi adalah merekomendasikan kepada pihak lain untuk melakukan pembelian hal ini merupakan suatu nilai positif yang ditunjukkan oleh konsumen terhadap perusahaan.

Berdasarkan kesimpulan yang telah diungkapkan di atas, maka saran-saran yang diajukan pada penelitian ini adalah sebagai berikut: 1) Upaya peningkatan penjualan agar meningkatkan minat beli konsumen, perusahaan perlu memperhatikan pengaruh lingkungan, citra pengembang, fasilitas, metode pembayaran dan produk. Namun tetap harus memperhatikan faktor-faktor lainnya yang dianalisa dalam penelitian ini seperti lokasi, harga, promosi dan faktor sosial. Hal ini karena faktor-faktor tersebut tidak mempengaruhi secara signifikan terhadap variabel konstruk terkait dengan keputusan pembelian; 2) Kepada peneliti berikutnya dapat melakukan penelitian dengan memasukkan variabel-variabel lainnya terkait dengan keputusan pembelian green product hunian, seperti kebutuhan konsumen, sikap konsumen, gaya hidup konsumen, motivasi, tingkat pendapatan, perkembangan informasi, perbaikan tingkat ekonomi dan pengetahuan.

\section{Daftar Pustaka}

Anastasia N. 2013. Peta Persepsi Konsumen terhadap Atribut Rumah Tinggal di Surabaya. Jurnal Manajemen dan Kewirausahaan, 5(2): 141-152.

Arianty D, Rohmana Y. 2012. Faktor-faktor yang mempengaruhi preferensi konsumen provider Indosat di perguruan tinggi negeri Kota Bandung. Jurnal Pendidikan Ekonomi dan Koperasi, 7(2).

Assael H. 1992. Consumer Behavior and Marketing Action. Ed ke-4. Boston (US): PWSKENT Publishing Company.

Bainana BP, Basuki A, Hidayat R. 2013. Identifikasi preferensi konsumen dalam minat beli rumah dengan pendekatan metode decision tree - studi kasus: perumahan Permata Indah Bangkalan. Jurnal Teknik Industri. Robust On Line, 1(1): 54-57.

Brahmanto Y. 2011. Pengaruh Karakteristik Pembeli terhadap Faktor-Faktor Pembelian Unit Rumah di Perumahan Graha Famili. [Thesis]. Surabaya (ID): Institut Teknologi Sepuluh November.

Chin WW. 1995. Partial least square is to LISREL as principal components analysis is to common factor analysis. Technology Studies, 2: 315-319.

Cooper DR, Schindler PS. 2006. Business Research Methods. Edisi ke-9. New York (US): McGraw Hill.

Craven DW. 1997. Pemasaran Strategis Ed Ke-4. Jakarta (ID): Erlangga. 
62|Wardhani, Sumarwan, Yuliati - Pengaruh Persepsi dan Preferensi Konsumen

Dahmiri. 2010. Analisis persepsi konsumen terhadap keputusan membeli perumahan Griya Kembar Lestari di Kota Jambi. Jurnal Pemasaran Modern, 2(1): 36-46.

Firsani T, Utomo C. 2012. Analisa life cycle cost pada green building diamond building Malaysia. Jurnal Teknik ITS. 1(1): 34-39.

Galaty F. 2006. Modern Real Estate Practice. Illinois (US): Dearbon Real Estate Education.

Garthwaite PH. 1994. An intrepretation of partial least squares. Journal of The American Statistical Association, 89(1): 411-425.

Gatignon H, Robertson TS. 1986. An Exchange Theory Model of Interpersonal Communication. Advances in Consumer Research. 13. eds. Richard J. Lutz, Provo, UT : Association for Consumer Research: 534-538.

Hair JF, Anderson RE, Tatham RL, Black WC. 2006. Multivariate Data Analysis. New Jersey (US): Prentice Hall International, Inc.

Hartono JM. 2008. Pedoman Survey Kuesioner: Mengembangkan Kuesioner, Mengatasi Bias dan Meningkatkan Respon. Yogyakarta (ID): Andi Offset.

Hawkins DI, Best RJ, Coney KA. 1997. Consumer Behavior: Building Marketing Strategy. New York (US): Mc Graw-Hill Companies, Inc.

Jogiyanto HM. 2011. Konsep dan Aplikasi Structural equation modeling SEM Berbasis Varian dalam Penelitian Bisnis. Yogyakarta (ID): Penerbit UPP STIM YKPN.

Kotler P. 2002. Marketing Management. Millenium Edition North Western University. New Jersey (US): Prentice Hall Inc.

Kotler P, Amstrong G. 2008. Prinsip-prinsip Pemasaran. Edisi Ke-12. Jakarta (ID): Airlangga.

Listyorini S. 2012. Analisis faktor-faktor gaya hidup dan pengaruhnya terhadap pembelian rumah sehat sederhana - studi pada pelanggan perumahaan Dinar Mas PT. Ajisaka di Semarang. Jurnal Administrasi Bisnis, 1(1): 12-24.

Nazir Y. 2008. Analisis Persepsi terhadap Kualitas Atribut Perumahan dan Pengaruhnya pada Willingness To Accept dari Kepemilikan Rumah-Studi Kasus Perumahan Sari Bunga Bakung Residence Bandung. [Thesis]. Yogyakarta (ID): Universitas Gadjah Mada.

Perreault WD, Cannon JP, McCarthy EJ. 2009. Basic Marketing: A Marketing Strategy Planning Approach. New York (US): McGraw Hill.

Pratikto HH. 2008. Preferensi Konsumen Perumahan terhadap Kondisi Fisik dan Ketersediaan Infrastruktur di Wilayah Kecamatan Gunungpati. [Thesis]. Semarang (ID): Universitas Diponegoro.

Rao AR, Monroe KB. 1988. The moderating effect of prior knowledge on cue utilization in product evaluations. Journal of Consumer Research, 15(2): 253-264.

Rustandi M. 2012. Analisis Preferensi dan Persepsi Konsumen Serta Implikasinya terhadap Pengembangan Kawasan Perumahan Baru Bogor Nirwana Residence. [Thesis]. Bogor (ID): Manajemen dan Bisnis Institut Pertanian Bogor.

Salisbury WD, Chin WW, Gopal A, Newsted PR. 2002. Research report: better theory through measurement-developing a scale to capture consensus on appropriation. Information System Research, 13: 91-103. 
Straughan RD, Roberts JA. 1999. Environmental segmentation alternatives: a look at green consumer behaviour in the new millennium. Journal of Consumer Marketing, 16(6): 558-575.

Sugito. 2004. Analisis Faktor-Faktor yang Mempengaruhi Perilaku Konsumen dalam Pengambilan Keputusan Pembelian Rumah PERUMNAS di Kota Medan. [Thesis]. Medan (ID): Universitas Sumatera Utara.

Sulistiyowati LN. 2008. Pengaruh persepsi atas produk dan pelayanan terhadap kepuasan pelanggan dan perilaku word of mouth wom - studi pada LBB " $X$ " Maospati Magetan. Jurnal Ilmiah Universitas Soerjo Ngawi. MEDIA SOERJO, 3(2): 17-32.

Sumarwan U. 2011. Perilaku Konsumen: Teori dan Penerapannya dalam Pemasaran. Bogor (ID): Penerbit Ghalia Indonesia.

Tambunan DB. 2009. Atribut yang menjadi pertimbangan konsumen dalam membeli produk perumahan. Integritas Jurnal manajemen Bisnis, 2(2): 141-153.

Tanata F. 2013. Pengaruh persepsi dan motivasi konsumen terhadap keputusan pembelian - studi kasus perumahan Poris Paradise Ekslusif Tangerang. Jurnal Manajemen.

Tjiptono F. 2008. Strategi Pemasaran. Edisi Ke-1. Yogyakarta (ID): Andi Offset.

Zeithaml VA. 1988. Consumer perception of price, quality and value: a means-end model and synthesis for evidence. Journal of Marketing, 52(3): 2-22. 